\title{
Retraction: The absence of MyD88 has no effect on the induction of alternatively activated macrophage during Fasciola hepatica infection
}

HongLin Luo ${ }^{1 *}$, Weiyi Huang ${ }^{2}$, Dongying Wang ${ }^{3,2}$, Haoju Wang ${ }^{1}$ and Kui Nie ${ }^{1}$

\section{Retraction}

The authors would like to retract the article "The absence of MyD88 has no effect on the induction of alternatively activated macrophage during Fasciola hepatica infection" published in BMC Immunology (2011, 12:63). The text and figures in this article [1] have been misappropriated from a different set of experiments using a different parasite, conducted in the laboratory of Prof J Allen and presented in the thesis of $\mathrm{K}$ Mylonas. Lead author Dr HongLin Luo accepts full responsibility for this and would like to apologise to colleagues in the lab, the co-authors, Editors and readers. The other authors take no responsibility for the misappropriation.

\footnotetext{
Author details

'Laboratory of Infection \& Immunology Research, College of Animal Science \& Technology, Southwest University, Chongqing, China. ${ }^{2}$ Parasitology department, College of Animal Science \& Technology, Guangxi University, Nanning, China. ${ }^{3}$ ENVA, UMR BIPAR, Ecopham, Ecole Nationale Vétérinaire d'Alfort, Maisons-Alfort, France.
}

Received: 16 January 2012 Accepted: 16 January 2012

Published: 16 January 2012

\section{Reference}

1. Luo H, Huang W, Wang D, Wang H, Nie K: The absence of MyD88 has no effect on the induction of alternatively activated macrophage during Fasciola hepatica infection. BMC Immunology 2011, 12:63.

\footnotetext{
* Correspondence: Ihl200296@yahoo.cn

'Laboratory of Infection \& Immunology Research, College of Animal Science

\& Technology, Southwest University, Chongqing, China

Full list of author information is available at the end of the article
}

Submit your next manuscript to BioMed Central and take full advantage of:

- Convenient online submission

- Thorough peer review

- No space constraints or color figure charges

- Immediate publication on acceptance

- Inclusion in PubMed, CAS, Scopus and Google Scholar

- Research which is freely available for redistribution 